\title{
Climate model simulation of the South Indian Ocean Convergence Zone: mean state and variability
}

\author{
Melissa J. Lazenby*, Martin C. Todd, Yi Wang \\ Department of Geography, University of Sussex, Brighton, East Sussex BN1 9RH, UK
}

\begin{abstract}
Evaluation of climate model performance at regional scales is essential in determining confidence in simulations of present and future climate. Here we developed a process-based approach focussing on the South Indian Ocean Convergence Zone (SIOCZ), a large-scale, austral summer rainfall feature extending across southern Africa into the southwest Indian Ocean. Simulation of the SIOCZ was evaluated for the Coupled Model Intercomparison Project (CMIP5). Comparison was made between CMIP5 and Atmospheric Model Intercomparison Project (AMIP) models to diagnose sources of biases associated with coupled ocean-atmosphere processes. Models were assessed in terms of mean SIOCZ characteristics and processes of interannual variability. Most models simulated a SIOCZ feature, but were typically too zonally oriented. A systematic bias of excessive precipitation was found over southern Africa and the Indian Ocean, but not particularly along the SIOCZ. Excessive precipitation over the continent may be associated with excessively high low-level moisture flux around the Angola Low found in most models, which is almost entirely due to circulation biases in models. AMIP models represented precipitation more realistically over the Indian Ocean, implying a potential coupling error. Interannual variability in the SIOCZ was evaluated through empirical orthogonal function analysis, where results showed a clear dipole pattern, indicative of a northeast-southwest movement of the SIOCZ. The drivers of this shift were significantly related to the El Niño Southern Oscillation and the subtropical Indian Ocean dipole in observations. However, the models did not capture these teleconnections well, limiting our confidence in model representation of variability.
\end{abstract}

KEY WORDS: CMIP5 - ENSO $\cdot$ Ensemble $\cdot$ Teleconnection $\cdot$ Model evaluation $\cdot$ South Indian Ocean Convergence Zone $\cdot$ SIOCZ $\cdot$ Southern Africa $\cdot$ December-January-February $\cdot$ DJF

\section{INTRODUCTION}

\subsection{Model evaluation}

Future projections of climate still contain a large amount of uncertainty, especially for precipitation (Schaller et al. 2011, Collins et al. 2013). In order to make future climate simulations with confidence, it is essential that models are able to adequately simulate the present climate (Sushama et al. 2006, Engelbrecht et al. 2009), as well as long-term mean circulation patterns and surface fields, and also particularly variability on all time scales (Battisti et al. 1995, Renwick \& Revell 1999, Engelbrecht et al. 2009).

\footnotetext{
*Corresponding author: M.Lazenby@sussex.ac.uk
}

Common evaluators of model performance include error (bias) against observations (Schaller et al. 2011) and correlations (spatial and temporal) between historical model simulations and observations (Taylor 2001). Complementary and more recent approaches to evaluate model performance suggest a processbased analysis to form a framework for evaluating model credibility (e.g. Gleckler et al. 2008, Thibeault \& Seth 2014). This includes evaluating a model's ability to capture the large-scale processes, such as the general circulation and variability of a particular feature or variable (Thibeault \& Seth 2014). The objective is to identify the mechanisms or processes causing future change in models, therefore not solely

๑ T The authors 2016. Open Access under Creative Commons by Attribution Licence. Use, distribution and reproduction are unrestricted. Authors and original publication must be credited. 
relying on representation of present climatology as an indicator of credibility in future projections (Shongwe et al. 2011, Thibeault \& Seth 2014, James et al. 2015).

\subsection{South Indian Ocean Convergence Zone (SIOCZ)}

The southern African climate is relatively understudied, and due to the region's generally high vulnerability to climate variability and change and low adaptive capacity, there is a growing demand from policymakers for more robust estimates of the future climate deemed sufficiently reliable to aid in decision making for adaption (Callaway 2004, Knutti et al. 2010). The southern African climate is dominated by the SIOCZ, a diagonal northwest to southeast band of enhanced low-level convergence and precipitation during austral summer extending from the southern African continent into the southwest Indian Ocean over the southeast coast from $10^{\circ}-40^{\circ} \mathrm{S}$ to $0-60^{\circ} \mathrm{E}$ (Cook 1998, 2000). It is a land-based convergence

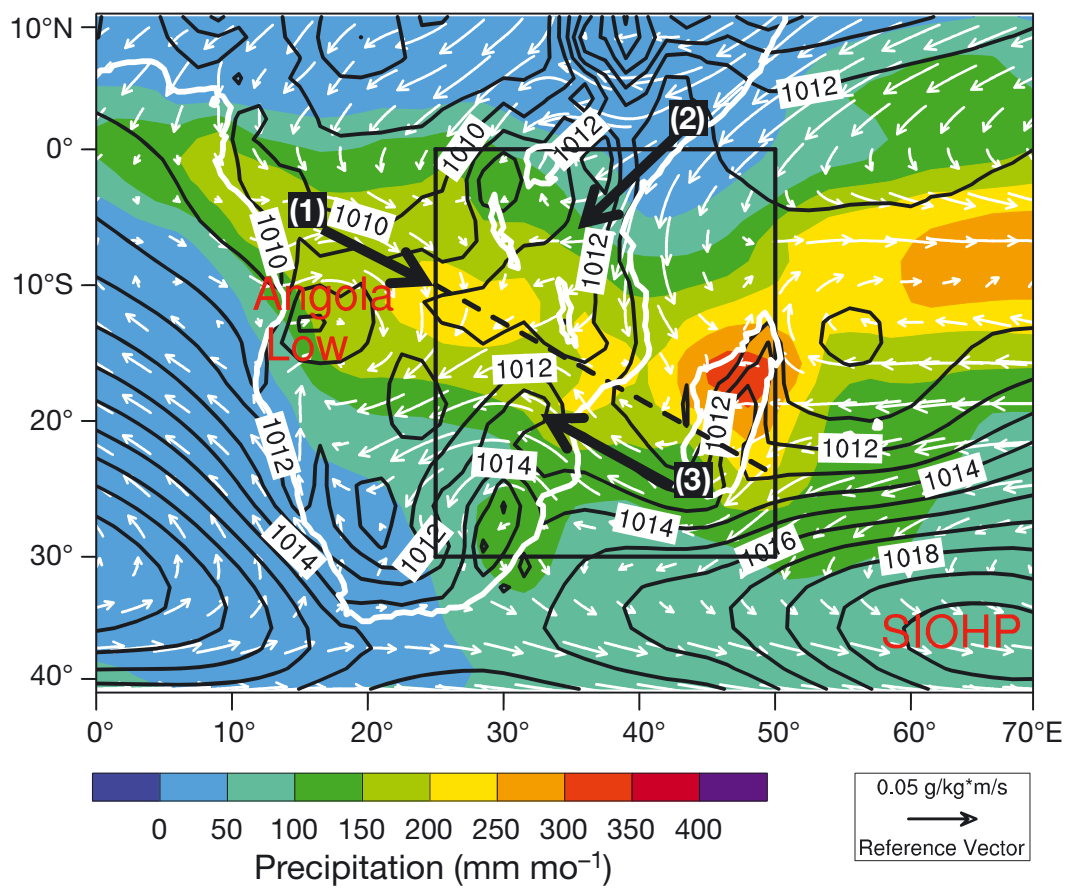

Fig. 1. Mean DJF climate over the study region, 1979/80-1998/99. Sea level pressure $(\mathrm{hPa}$, solid black lines from ERA-Interim data), precipitation (colour; source: CMAP) and moisture flux at $850 \mathrm{hPa}\left(\mathrm{g} \mathrm{kg}^{-1} \mathrm{~m} \mathrm{~s}^{-1}\right.$, white arrows - length is indicative of magnitude from ERA-Interim). Black box indicates the chosen South Indian Ocean Convergence Zone (SIOCZ) region $\left(0-30^{\circ} \mathrm{S}, 25-50^{\circ} \mathrm{E}\right)$ and the dashed black line represents the SIOCZ. Black arrows labelled 1,2,3 represent the 3 major moisture flux pathways into the SIOCZ (see the Introduction for details). SIOHP: South Indian Ocean High Pressure zone that forms the dynamic link between the largescale circulation and the precipitation over southern Africa and the southwestern Indian Ocean (Tyson 1986, Cook 1998, 2000, Ninomiya 2008). It can be identified using variables such as outgoing longwave radiation (OLR), convergence fields, vertical uplift, high clouds and mean sea level pressure (SLP), which has been done previously to identify the South Atlantic Convergence Zone (SACZ) (Liebmann et al. 1999) and the South Pacific Convergence Zone (SPCZ) (Brown et al. 2011).

The zonal wind convergence occurring between the thermal low (Angola Low) and the South Indian Ocean High Pressure (SIOHP, also known as the Mascarene high pressure) are responsible for the dominant boundary of the SIOCZ over the southern African continent (Cook 2000, Ninomiya 2008) (Fig. 1). The extension of the SIOCZ into the Indian Ocean is mainly a result of the partially compensating influences of moisture advection and moist transient eddy activity and meridonal wind convergence (Cook 2000). Three clear sources of moisture flux to be noted in Fig. 1 are (1) from the circulation around the Angola Low, (2) from the NE monsoon region and (3) from the circulation around the SIOHP that ridges over the continent.

Climate variability over southern Africa and the southwestern Indian Ocean is dominated by a dipole pattern in OLR, convection and rainfall, which can be interpreted as the interannual shift in the position of the SIOCZ (Cook 2000) (see Section 5 below). This dipole between the northeastern regions and the eastern African regions (Cook 1998) has a strong association with El Niño Southern Oscillation (ENSO) and the Indian Ocean (Makarau \& Jury 1997, Goddard \& Graham 1999, Nicholson et al. 2001, Hoerling et al. 2006, Rowell 2013). The subtropical Indian Ocean dipole (SIOD) is important in understanding southern African rainfall variability over interannual time scales (Goddard \& Graham 1999, Cook 2000, Behera \& Yamagata 2001, Reason 2001).

In this paper, models are evaluated in terms of their ability to simulate the mean state of the SIOCZ and variability on an interannual time scale. The drivers of interannual variability will also be identified in observations and models. 
The simulation of the SIOCZ has not previously been evaluated using this suite of climate models, and information about the SIOCZ in models will provide input for evaluating uncertainty in regional climate projections for southern Africa.

\section{DATA AND METHODS}

\subsection{Data}

The gridded precipitation observational dataset used here was the monthly Climate Prediction Center Merged Analysis of Precipitation (CMAP, Xie \& Arkin 1997). Other precipitation gridded gauge datasets were tested with essentially equivalent results (i.e. the Global Precipitation Climatology Project, GPCP; Adler et al. 2003, Yin et al. 2004). Other observed datasets used include NOAA sea surface temperatures (SSTs; Reynolds et al. 2007) and ERAInterim reanalysis fields (Dee et al. 2011).

Twentieth century simulations from a total of 44 models from the World Climate Research Programme (WCRP) Coupled Model Intercomparison Project Phase 5 (CMIP5) multi-model dataset, in the most recent (Fifth) Assessment Report of the Intergovernmental Panel on Climate Change were used (Meehl et al. 2007, Taylor et al. 2012) (Table 1). Additionally, 27 Atmospheric Model Intercomparison Project (AMIP) (Gates 1992, Gates et al. 1999) were analysed to attribute the source of biases. Monthly data were extracted for the December-January-February (DJF) austral summer season of key diagnostic variables to understand essential processes of southern African climate.

\subsection{Model performance metrics}

The ability of models to capture the SIOCZ structure is derived through spatial correlations of the mean observed and modelled precipitation over the SIOCZ region (domain: $0-30^{\circ} \mathrm{S}, 25-50^{\circ} \mathrm{E}$, illustrated by the black rectangle in Fig. 1). Model error is quantified through mean bias and root mean square errors (RMSEs; metrics listed in Table 2).

To diagnose model errors, we determine the errors in the structure of low-level moisture flux into the SIOCZ region in models to understand the key controls in the formation and maintenance the SIOCZ. SST climatology is also assessed in multi-model ensembles to investigate the links and potential relationships between SSTs and precipitation.
To determine SIOCZ variability, empirical orthogonal functions (EOFs) of DJF precipitation, for a $30 \mathrm{yr}$ period over southern Africa, are derived for both models and observations. The first 3 EOFs are calculated for observations, as well as for all CMIP5 and AMIP models, from which the EOF with the highest association with the observed EOF 1 is chosen for further model analysis. Composite analysis of specific humidity and zonal and meridonal winds are evaluated to link the large-scale circulation to interannual variability of the SIOCZ. Global maps correlating the EOF (time coefficients) to global SSTs are created to determine major SST teleconnection regions.

\section{MODEL REPRESENTATION OF THE SIOCZ}

\subsection{SIOCZ climatology bias}

As discussed in Section 1 above, southern African austral summer climate is dominated by the SIOCZ, which is driven by the circulation around the Angola Low and SIOHP, and an additional influx from the northwestern region. These 3 moisture flux pathways converge at low levels $(850 \mathrm{hPa})$ to form the SIOCZ (Fig. 1).

The zonal mean precipitation distribution indicates that most CMIP5 models overestimate the intensity of precipitation over the SIOCZ region in some models by up to $100 \mathrm{~mm} \mathrm{mo}^{-1}$ (Fig. 2). The overall model bias over the SIOCZ region is $24 \mathrm{~mm} \mathrm{mo}^{-1}$, which is $18 \%$ of the observed mean of $135 \mathrm{~mm} \mathrm{mo}^{-1}$ (Table 2), with a standard deviation (not shown) of $17 \mathrm{~mm} \mathrm{mo}^{-1}$. This indicates that the multi-model mean (MMM) is relatively close to observations; however, individual models show relatively high positive biases as well as excessively large RMSEs. Model RMSEs average $71 \mathrm{~mm} \mathrm{mo}^{-1}$, which is approximately $53 \%$ or over a factor of 2 in excess of the climatological mean.

\subsection{Spatial structure of the SIOCZ}

The majority of CMIP5 models capture the spatial distribution of precipitation reasonably well in terms of identifying the SIOCZ (Fig. 3). Main points to note are (1) models exhibit a lack of continuity in the SIOCZ, i.e. a clear break in precipitation is seen between land and ocean, and (2) the majority of models simulate excessive precipitation over the southern African continent and adjacent Indian Ocean.

The multi-model ensembles (MMEs) for both CMIP5 and AMIP have a SIOCZ that is relatively 
Table 1. CMIP5 models $(\mathrm{n}=44)$ used in this study, including modelling centre, institute ID and atmospheric resolution. ${ }^{*}$ Models for which the atmosphere-only version was also used in the analysis

\begin{tabular}{|c|c|c|c|}
\hline & Modelling centre (or group) & Institute ID & $\begin{array}{l}\text { Atmospheric } \\
\text { resolution }\end{array}$ \\
\hline $\begin{array}{l}\text { ACCESS1.0* } \\
\text { ACCESS1.3* }\end{array}$ & $\begin{array}{l}\text { Commonwealth Scientific and Industrial Research Organisation (CSIRO) } \\
\text { and Bureau of Meteorology (BOM), Australia }\end{array}$ & CSIRO-BOM & $1.25^{\circ} \times 1.9^{\circ}$ \\
\hline $\begin{array}{l}\text { BCC-CSM1.1* } \\
\text { BCC-CSM1.1(m) }\end{array}$ & Beijing Climate Center, China Meteorological Administration & $\mathrm{BCC}$ & $\begin{array}{c}2.8^{\circ} \times 2.8^{\circ} \\
1.12^{\circ} \times 1.12^{\circ}\end{array}$ \\
\hline BNU-ESM* & College of Global Change and Earth System Science, Beijing Normal University & GCESS & $2.8^{\circ} \times 2.8^{\circ}$ \\
\hline $\begin{array}{l}\text { CanESM2 } \\
\text { CanAM4* }\end{array}$ & Canadian Centre for Climate Modelling and Analysis & CCCMA & $2.8^{\circ} \times 2.8^{\circ}$ \\
\hline $\mathrm{CCSM}^{*}$ & National Center for Atmospheric Research & NCAR & $0.94^{\circ} \times 1.25^{\circ}$ \\
\hline $\begin{array}{l}\text { CESM1(BGC) } \\
\text { CESM1(CAM5) } \\
\text { CESM1(FASTCHEM) } \\
\text { CESM1(WACCM) }\end{array}$ & Community Earth System Model Contributors & NSF-DOE-NCAR & $0.94^{\circ} \times 1.25^{\circ}$ \\
\hline $\begin{array}{l}\text { CMCC-CESM } \\
\text { CMCC-CM* } \\
\text { CMCC-CMS }\end{array}$ & Centro Euro-Mediterraneo per i Cambiamenti Climatici & CMCC & $\begin{array}{r}3.71^{\circ} \times 3.75^{\circ} \\
0.75^{\circ} \times 0.75^{\circ} \\
1.9^{\circ} \times 1.9^{\circ}\end{array}$ \\
\hline CNRM-CM5* & $\begin{array}{l}\text { Centre National de Recherches Météorologiques / Centre Européen } \\
\text { de Recherche et Formation Avancée en Calcul Scientifique }\end{array}$ & CNRM-CERFACS & $1.4^{\circ} \times 1.4^{\circ}$ \\
\hline CSIRO-Mk3.6.0* & CSIRO in collaboration with Queensland Climate Change Centre of Excellence & CSIRO-QCCCE & $1.9^{\circ} \times 1.9^{\circ}$ \\
\hline EC-EARTH* & EC-EARTH consortium & EC-EARTH & $1.1^{\circ} \times 1.1^{\circ}$ \\
\hline FGOALS-g2* & $\begin{array}{l}\text { LASG, Institute of Atmospheric Physics, Chinese Academy of Sciences } \\
\text { and CESS, Tsinghua University }\end{array}$ & LASG-CESS & $2.8^{\circ} \times 2.8^{\circ}$ \\
\hline FGOALS-s $2^{*}$ & LASG, Institute of Atmospheric Physics, Chinese Academy of Sciences & LASG-IAP & $1.7^{\circ} \times 2.8^{\circ}$ \\
\hline FIO-ESM & The First Institute of Oceanography, SOA, China & FIO & $2.8^{\circ} \times 2.8^{\circ}$ \\
\hline $\begin{array}{l}\text { GFDL-CM3* } \\
\text { GFDL-ESM2G } \\
\text { GFDL-ESM2M } \\
\text { GFDL-HIRAM-C180* } \\
\text { GFDL-HIRAM-C360* }\end{array}$ & NOAA Geophysical Fluid Dynamics Laboratory & NOAA GFDL & $2.0^{\circ} \times 2.5^{\circ}$ \\
\hline $\begin{array}{l}\text { GISS-E2-H } \\
\text { GISS-E2-H-CC } \\
\text { GISS-E2-R* } \\
\text { GISS-E2-R-CC }\end{array}$ & NASA Goddard Institute for Space Studies & NASA GISS & $2.0^{\circ} \times 2.5^{\circ}$ \\
\hline HadGEM2-AO & $\begin{array}{l}\text { National Institute of Meteorological Research/Korea Meteorological } \\
\text { Administration }\end{array}$ & NIMR/KMA & $1.25^{\circ} \times 1.9^{\circ}$ \\
\hline $\begin{array}{l}\text { HadGEM2-CC } \\
\text { HadGEM2-ES } \\
\text { HadGEM2-A* }\end{array}$ & $\begin{array}{l}\text { Met Office Hadley Centre (additional HadGEM2-ES realizations } \\
\text { contributed by Instituto Nacional de Pesquisas Espaciais) }\end{array}$ & $\begin{array}{l}\text { MOHC } \\
\text { (additional } \\
\text { alizations by INPE) }\end{array}$ & $1.25^{\circ} \times 1.9^{\circ}$ \\
\hline INM-CM4* & Institute for Numerical Mathematics & INM & $1.5^{\circ} \times 2^{\circ}$ \\
\hline $\begin{array}{l}\text { IPSL-CM5A-LR* } \\
\text { IPSL-CM5A-MR * } \\
\text { IPSL-CM5B-LR* }^{*}\end{array}$ & Institut Pierre-Simon Laplace & IPSL & $\begin{array}{l}1.9^{\circ} \times 3.75^{\circ} \\
1.25^{\circ} \times 2.5^{\circ} \\
1.9^{\circ} \times 3.75^{\circ}\end{array}$ \\
\hline $\begin{array}{l}\text { MIROC-ESM } \\
\text { MIROC-ESM-CHEM }\end{array}$ & $\begin{array}{l}\text { Japan Agency for Marine-Earth Science and Technology, Atmosphere and } \\
\text { Ocean Research Institute (The University of Tokyo), and National Institute for } \\
\text { Environmental Studies }\end{array}$ & MIROC & $2.8^{\circ} \times 2.8^{\circ}$ \\
\hline $\begin{array}{l}\text { MIROC4h } \\
\text { MIROC5* }\end{array}$ & $\begin{array}{l}\text { Atmosphere and Ocean Research Institute (The University of Tokyo), National } \\
\text { Institute for Environmental Studies, and Japan Agency for Marine-Earth Science } \\
\text { and Technology }\end{array}$ & MIROC & $\begin{array}{r}0.56^{\circ} \times 0.56^{\circ} \\
1.4^{\circ} \times 1.4^{\circ}\end{array}$ \\
\hline $\begin{array}{l}\text { MPI-ESM-LR* } \\
\text { MPI-ESM-MR* } \\
\text { MPI-ESM-P }\end{array}$ & Max-Planck-Institut für Meteorologie (Max Planck Institute for Meteorology) & MPI-M & $1.9^{\circ} \times 1.9^{\circ}$ \\
\hline MRI-CGCM3* & Meteorological Research Institute & MRI & $1.1^{\circ} \times 1.1^{\circ}$ \\
\hline $\begin{array}{l}\text { NorESM1-M* } \\
\text { NorESM1-ME }\end{array}$ & Norwegian Climate Centre & $\mathrm{NCC}$ & $1.9^{\circ} \times 2.5^{\circ}$ \\
\hline
\end{tabular}


Table 2. Spatial correlations of precipitation between observations (CMAP) and CMIP5 models over the South Indian Ocean Convergence Zone (SIOCZ) region. Area averages, model biases and root mean square error (RMSE) calculated over the SIOCZ region. All calculations based on the period 1979/80-1998/99. (/) Not applicable

\begin{tabular}{|c|c|c|c|c|}
\hline $\begin{array}{l}\text { Name of model/ } \\
\text { observation }\end{array}$ & $\begin{array}{l}\text { SIOCZ } \\
\text { region } \\
\text { spatial } \\
\text { correlation }\end{array}$ & $\begin{array}{c}\text { Area } \\
\text { average } \\
\left(\mathrm{mm} \mathrm{mo}^{-1}\right)\end{array}$ & $\begin{array}{c}\text { Model } \\
\text { bias } \\
\left(\mathrm{mm} \mathrm{mo}^{-1}\right)\end{array}$ & $\begin{array}{c}\text { Model } \\
\text { RMSE } \\
\left(\mathrm{mm} \mathrm{mo}^{-1}\right)\end{array}$ \\
\hline CMAP & / & 135 & / & / \\
\hline ACCESS1-0 & 0.85 & 159 & 24 & 63 \\
\hline ACCESS1-3 & 0.77 & 183 & 48 & 94 \\
\hline bcc-csm1-1 & 0.85 & 144 & 9 & 42 \\
\hline bcc-csm1-1-m & 0.84 & 138 & 3 & 47 \\
\hline BNU-ESM & 0.75 & 180 & 45 & 86 \\
\hline CanESM2 & 0.82 & 150 & 15 & 59 \\
\hline CCSM4 & 0.85 & 180 & 45 & 72 \\
\hline CESM1-BGC & 0.85 & 177 & 42 & 71 \\
\hline CESM1-CAM5 & 0.87 & 156 & 21 & 53 \\
\hline CESM1-FASTCHEM & 0.84 & 174 & 39 & 70 \\
\hline CESM1-WACCM & 0.74 & 174 & 39 & 80 \\
\hline CMCC-CESM & 0.74 & 147 & 12 & 57 \\
\hline CMCC-CM & 0.77 & 126 & -9 & 49 \\
\hline CMCC-CMS & 0.75 & 147 & 12 & 56 \\
\hline CNRM-CM5 & 0.70 & 153 & 18 & 58 \\
\hline CSIRO-Mk3-6-0 & 0.75 & 135 & 0 & 78 \\
\hline EC-EARTH & 0.81 & 147 & 12 & 46 \\
\hline FGOALS-g2 & 0.83 & 114 & -21 & 44 \\
\hline FGOALS-s2 & 0.80 & 129 & -6 & 51 \\
\hline FIO-ESM & 0.57 & 165 & 30 & 91 \\
\hline GFDL-CM3 & 0.81 & 174 & 39 & 68 \\
\hline GFDL-ESM2G & 0.78 & 192 & 57 & 89 \\
\hline GFDL-ESM2M & 0.81 & 192 & 57 & 84 \\
\hline GISS-E2-H & 0.73 & 138 & 3 & 65 \\
\hline GISS-E2-H-CC & 0.66 & 138 & 3 & 76 \\
\hline GISS-E2-R & 0.73 & 129 & -6 & 70 \\
\hline GISS-E2-R-CC & 0.74 & 129 & -6 & 68 \\
\hline HadGEM2-AO & 0.84 & 156 & 21 & 67 \\
\hline HadGEM2-CC & 0.84 & 150 & 15 & 58 \\
\hline HadGEM2-ES & 0.83 & 150 & 15 & 64 \\
\hline inmcm4 & 0.82 & 150 & 15 & 57 \\
\hline IPSL-CM5A-LR & 0.72 & 174 & 39 & 81 \\
\hline IPSL-CM5A-MR & 0.73 & 177 & 42 & 88 \\
\hline IPSL-CM5B-LR & 0.84 & 159 & 24 & 58 \\
\hline MIROC4h & 0.67 & 171 & 36 & 86 \\
\hline MIROC5 & 0.70 & 189 & 54 & 103 \\
\hline MIROC-ESM & 0.48 & 174 & 39 & 105 \\
\hline MIROC-ESM-CHEM & 0.55 & 177 & 42 & 100 \\
\hline MPI-ESM-LR & 0.68 & 162 & 27 & 67 \\
\hline MPI-ESM-MR & 0.69 & 165 & 30 & 71 \\
\hline MPI-ESM-P & 0.68 & 156 & 21 & 64 \\
\hline MRI-CGCM3 & 0.76 & 132 & -3 & 60 \\
\hline NorESM1-M & 0.54 & 189 & 54 & 107 \\
\hline NorESM1-ME & 0.58 & 189 & 54 & 103 \\
\hline Model mean $(n=44)$ & 0.79 & 159 & 24 & 71 \\
\hline
\end{tabular}

land and the Indian Ocean, the SIOCZ is potentially being relatively underestimated in models. AMIP has reduced these biases in both regions, demonstrating a coupled model error. Both MME plots show the SIOCZ to be too zonal in structure, particularly the CMIP5 MME.

SSTs are overlaid on the CMIP5 MME bias plot (Fig. 4b) to potentially understand the large ocean precipitation bias. A small negative SST bias (ca. $-0.5^{\circ} \mathrm{C}$ ) is found over the Indian Ocean, therefore not explicitly explaining the overestimation of precipitation in this area by means of an overly warm ocean. Over the Atlantic Ocean, there is a large positive SST bias $\left(\sim 2^{\circ} \mathrm{C}\right)$, which may be linked to the precipitation bias over this region. However, both thermodynamic (local SST) and dynamic (circulation) components can contribute to precipitation biases. In recent studies by Bollasina \& Ming (2013), the dynamic contribution tends to explain the excessive precipitation bias through anomalous circulation over the Indian Ocean.

Spatial correlations between observed and modelled DJF precipitation over the SIOCZ region are shown in Table 2 . The majority of models have a correlation coefficient above 0.7, and only 1 model (MIROC-ESM) below 0.5, therefore confirming that the vast majority of the models are able to capture the spatial structure of the summer rainfall patterns well over the SIOCZ region. Models with the highest spatial correlations, e.g. bcccsm1-1 (0.85) and CESM1-CAM5 (0.87), also tend to have the lowest or lower biases (0.3 and 0.7) and RMSEs (1.41 and 1.77).

\subsection{Moisture flux and large-scale regional circulation}

The MME moisture flux bias shows that models on average over-simulate the 3 sources of moisture flux into the SIOCZ, particularly moisture flux pathway 2 from the NE Monsoon flow (from Fig. 1), as well as the lowlevel moisture flux around the Angola Low, viz. moisture flux pathway 1 , where more moisture flux con-

vergence (orange and red shading) is evident in underestimated when compared to the positive precipitation bias over the continent and Indian Ocean (Fig. 4). The SIOCZ does not have a negative bias; however, when compared to the excessive bias over 


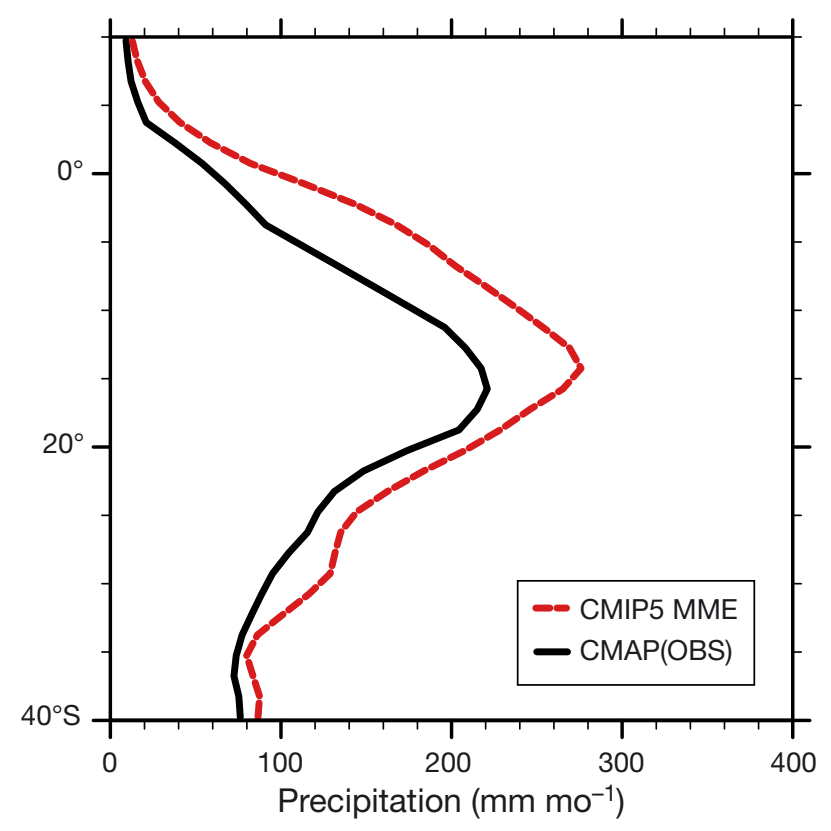

Fig 2. Zonal mean (averaged over longitudes 25 to $50^{\circ} \mathrm{E}$ ) DJF precipitation from observations (CMAP - solid bold black line), and CMIP5 multi-model ensemble (MME, dashed red line) for the period 1979/80-1998/99. See Fig. S1 in the Supplement (www.int-res.com/articles/suppl/c068p059 _supp.pdf) for the chart with all 44 individual CMIP5 models

Fig. 5a. This may explain the excessive precipitation found over the continent in models. To deduce whether moisture (specific humidity) or circulation (zonal and meridonal winds) contributes less/more/ equally to the moisture flux bias, plots of observed specific humidity and MME wind bias and observed winds and MME-specific humidity biases at $850 \mathrm{hPa}$ are shown in Fig. 5b,c. By plotting 1 observed component and $1 \mathrm{MME}$ component of moisture flux at a time, this can determine which variable contributes most to the moisture flux bias. In this case, the circulation component is almost solely responsible for the bias of moisture flux in CMIP5 models.

Fig. 6 shows 3 individual model biases for $850 \mathrm{hPa}$ moisture flux and moisture flux magnitude. ACCESS1-0 shows a moisture flux bias pattern most representative of most CMIP5 models. FGOALS-g2 bias is lower than most models and notably does not exhibit excessive precipitation in the DJF climatology (Fig. 3). MIROC-ESM-CHEM exhibits large biases from all 3 moisture flux pathways identified in Fig. 1. It is interesting to note that very wet models (seen in Fig. 3) tend to show excessive moisture flux in excessively wet regions. For example, ACCESS1-3 and MIROC-ESM-CHEM exhibit excessive precipitation over central southern Africa, and both models show a large positive bias of low-level moisture flux over the same region. Therefore, low-level moisture flux in models that is erroneously high may be a reason for the precipitation bias, particularly over the continent (e.g. Washington et al. 2013).

\section{INTERANNUAL VARIABILITY OF THE SIOCZ}

\subsection{Observed variability}

Interannual modes of SIOCZ variability in both observations and models are determined using EOF analysis. In observations, variability is characterised by a clear dipole pattern, which can be interpreted as a NE-SW shift in the position of the SIOCZ axis (Fig. 7) (Cook 2001). Composite analysis was applied to other diagnostic fields, specifically low-level specific humidity and wind reanalysis fields. The top minus the bottom 5 years from observed EOF 1 time series were derived. The variability of the wind circulation appears to be driven by anomalously strong anti-cyclonic circulation in the southwestern Indian Ocean (Fig. 8), which brings in moisture from the Indian Ocean into the convergence zone (moisture flux pathway 3, see Fig. 1).

SIOCZ is clearly associated with dominant global and regional modes of interannual variability, apparent through correlations of EOF 1 time coefficients with global tropical SSTs (Fig. 9, Table 3). Specifically, there is a significant correlation with ENSO and the SIOD at the $95 \%$ confidence interval (Table 3). The mean position of the SIOCZ lies approximately between the dipole pattern as shown in EOF 1 in Fig. 7, consistent with previous analysis (e.g. Cook 2001). Therefore, the dipole pattern is indicating the variability of this feature, which is dominated by ENSO and the Indian Ocean (see Fig. 9).

\subsection{Model variability}

In the majority of models, a NW/SE dipole pattern indicative of the SIOCZ interannual variability emerges in the leading EOF. We found no notable difference in skill between the CMIP5 and AMIP EOF plots. For 7 CMIP5 models, there is no discernable SIOCZ dipole pattern similar to observations.

Observed drivers of variability are clearly distinguishable from Fig. 9, with regions of highest correlations ( 0.4) over the central Pacific and Indian Ocean. These global plots were replicated for CMIP5 and AMIP, but are not shown due to space constraints. Of 44 CMIP5 models, 17 have EOF spatial 

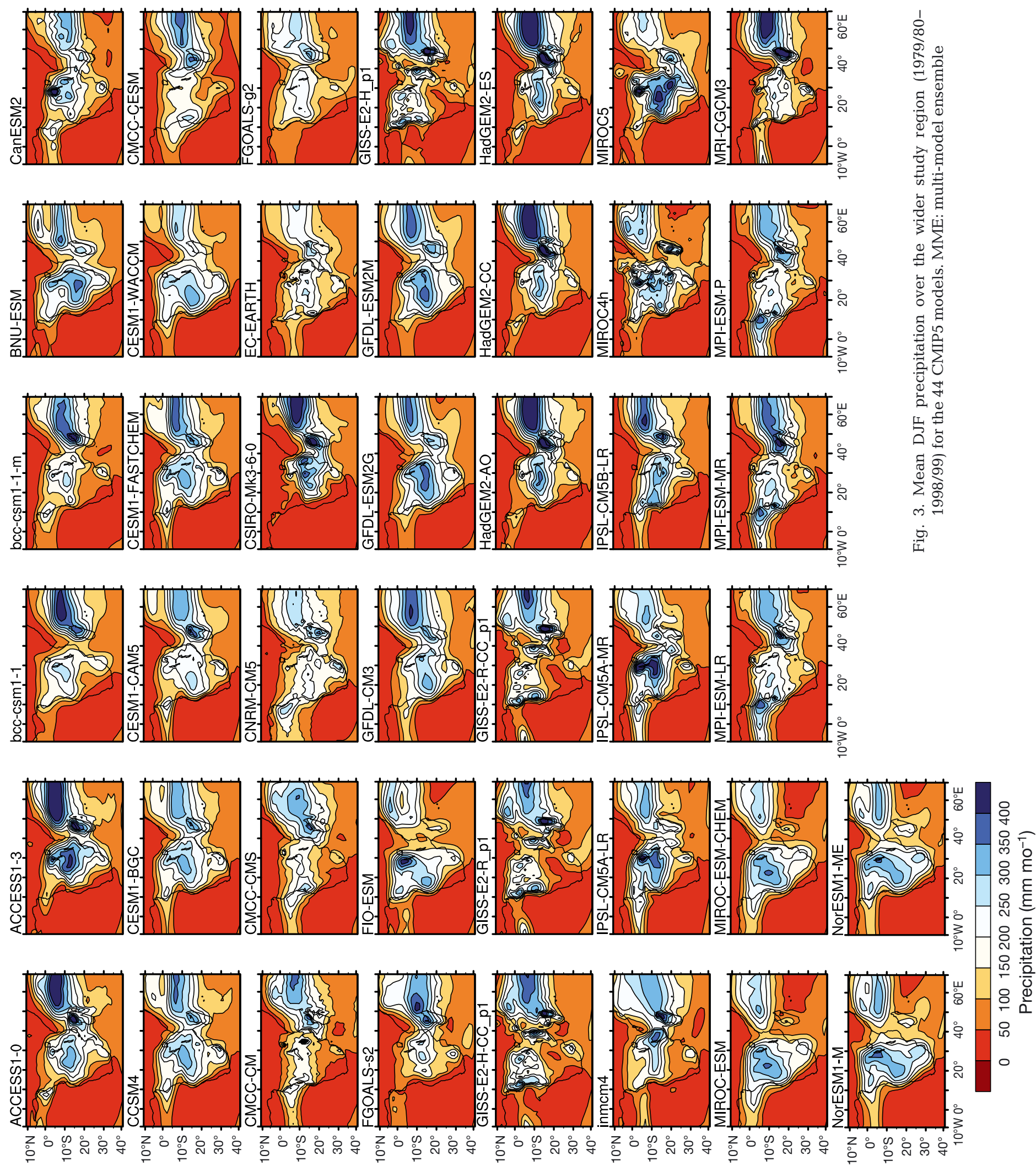
a) CMIP5 MME

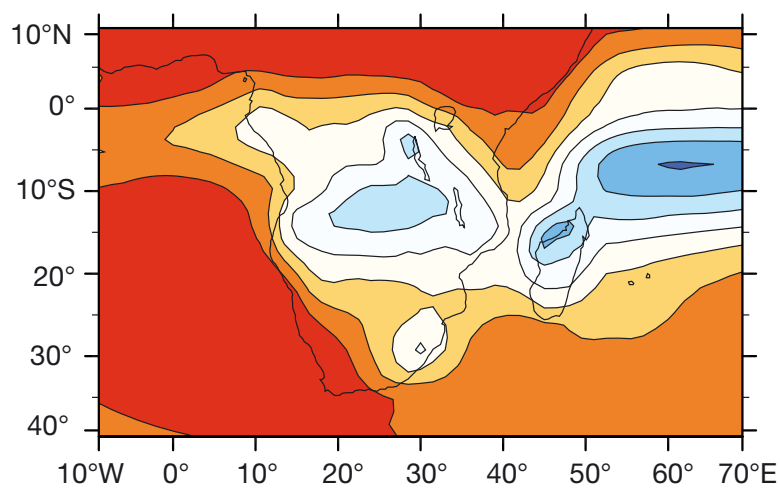

c) AMIP MME

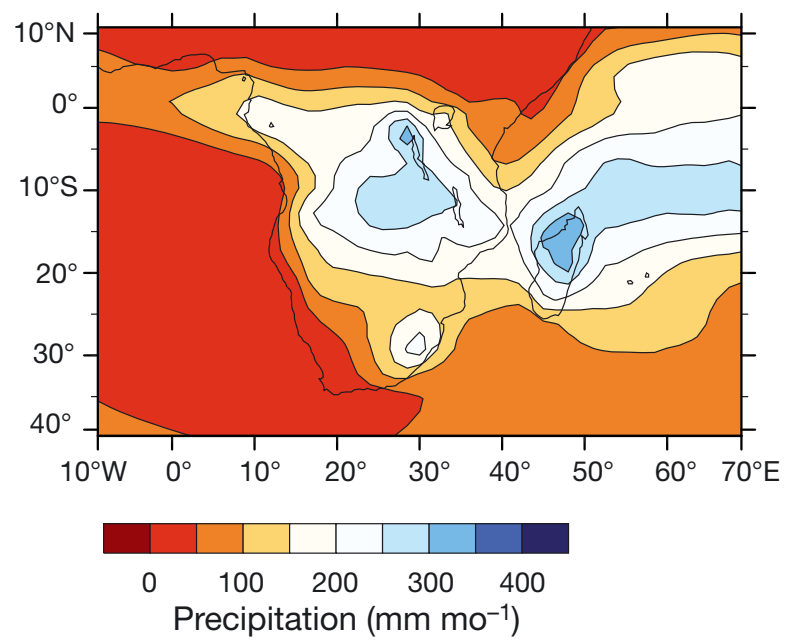

b) CMIP5 MME bias

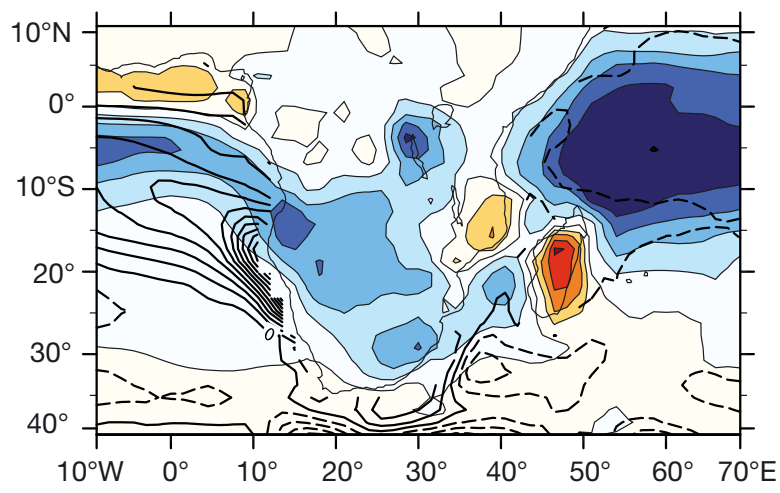

d) AMIP MME bias

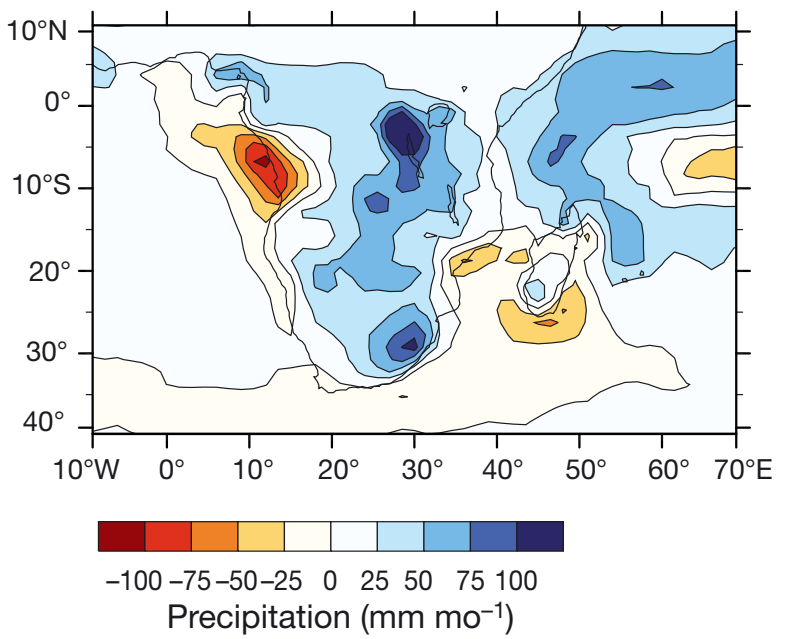

Fig. 4. Model simulations of precipitation in the study region. Multi-model ensemble (MME) mean DJF precipitation (mm $\left.\mathrm{mo}^{-1}, 1979 / 80-1998 / 99\right)$ from (a,b) CMIP5 and (c,d) AMIP (c) model runs (using the 27 models in common) and their respective biases against CMAP (see Fig. 1). In (b) SST MME mean bias from CMIP is overlaid (black contours with $0.5 \mathrm{~K}$ interval where solid lines are positive and dashed lines indicate negative values

correlations $>0.6$ compared to the observed EOF 1 , and for 6 of these models, correlations of $>0.6$ are found in EOF 2. Of the 17 models that exhibit this dipole, only 9 depict global SST correlation patterns similar to observations, i.e. with highest correlations found over the Pacific and Indian Ocean.

Therefore, the majority of CMIP5 models are not able to capture the relationship between the Pacific and Indian Ocean as in observations, i.e. teleconnections. Three examples of these global correlation maps (CESM1-BGC: good, bcc-csm1-1: average, and MPI-ESM_P: poor) are shown in Fig. 10. The vast majority of models are not able to capture the observed teleconnections, but are evidently better at capturing the ENSO teleconnection than the Indian Ocean influence (SIOD) (Table 3).

\section{DISCUSSION AND CONCLUSIONS}

The first key conclusion from this study is that the majority of CMIP5 models perform well at simulating the spatial pattern of seasonal rainfall for DJF over southern Africa. An overall systematic bias toward an excessively wet southern African region is found, which is confirmed by the predominant amount of positive model biases and high RMSEs. However, the SIOCZ itself is not particularly wet; rather, the surrounding regions exhibit excessive precipitation. Reasons for the SIOCZ itself not being particularly wet may be due to the dominant bias in the Indian Ocean as well as circulation biases that enhance moisture flux into the surrounding regions. There is a noticeable break in the SIOCZ in the vast majority of models between land and ocean. A potential reason 
a) CMIP5 MME BIAS (qu;qv)

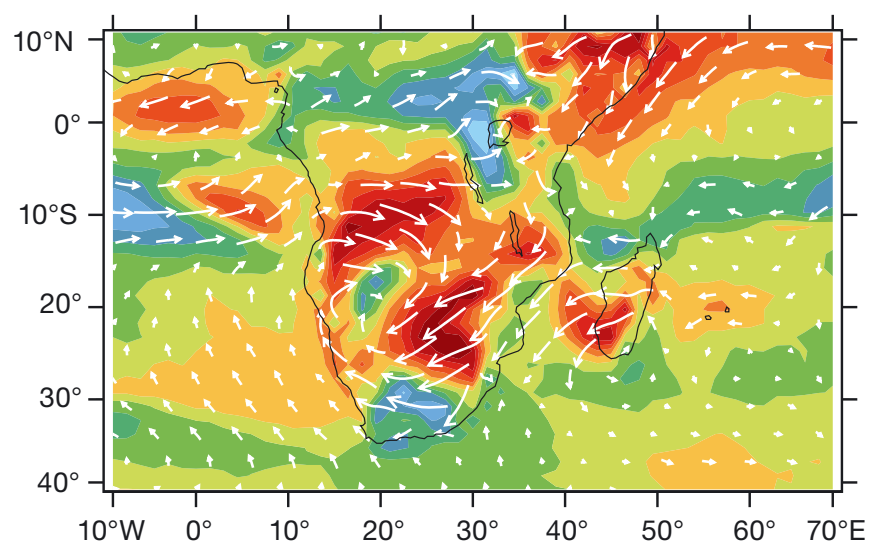

b) BIAS: MME q \& obs uv

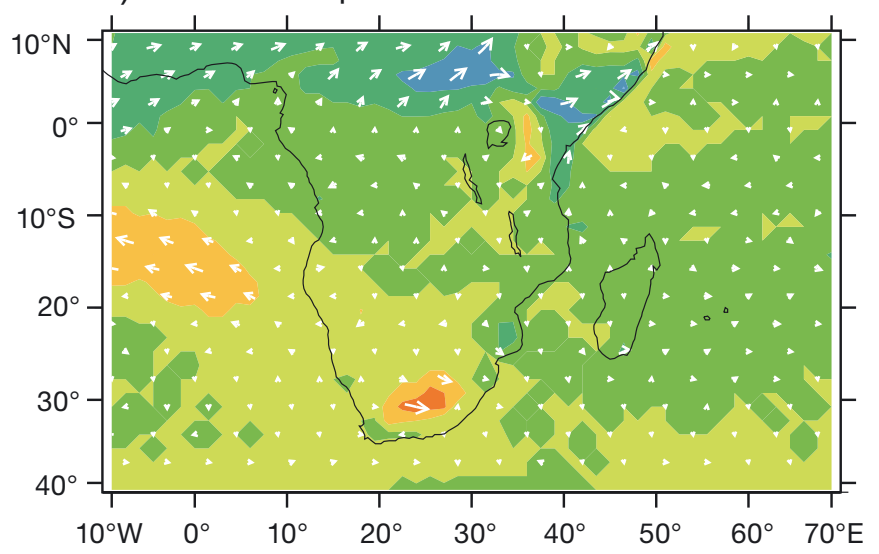

c) BIAS: MME uv \& obs q

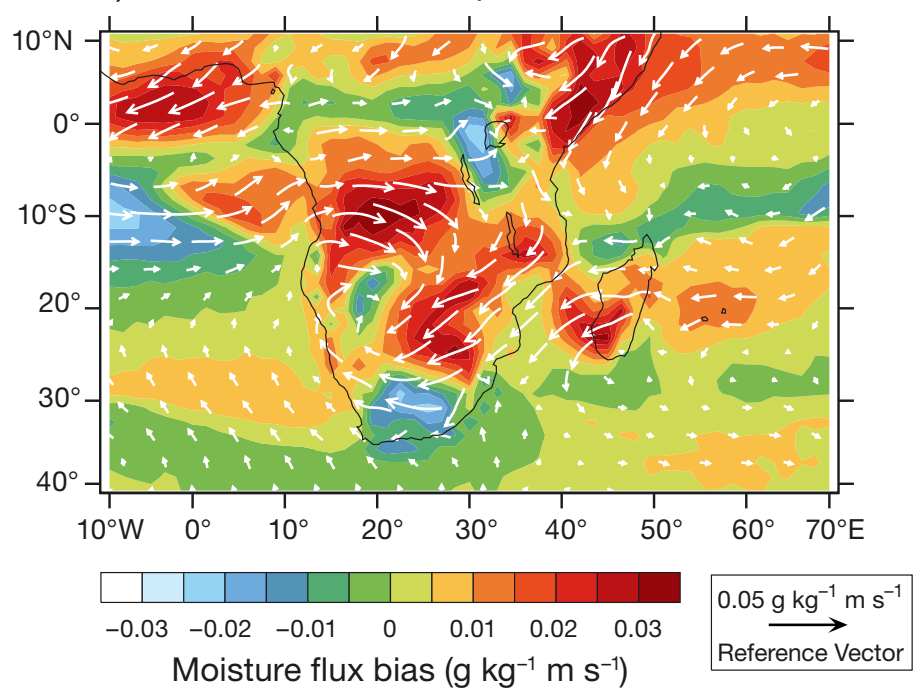

Fig 5. (a) CMIP DJF $850 \mathrm{hPa}$ moisture flux bias $\left(\mathrm{g} \mathrm{kg}^{-1} \mathrm{~m} \mathrm{~s}^{-1}\right.$, magnitude shaded) for the period 1979/80-1998/99. (b) As in panel (a), but derived using observed ERA-Interim winds and CMIP MME mean specific humidity bias. (c) Same as in panel (a), but derived using observed ERA-Interim specific humidity (q) and CMIP MME mean $u$ and $v$ wind biases
ACCESS1-3

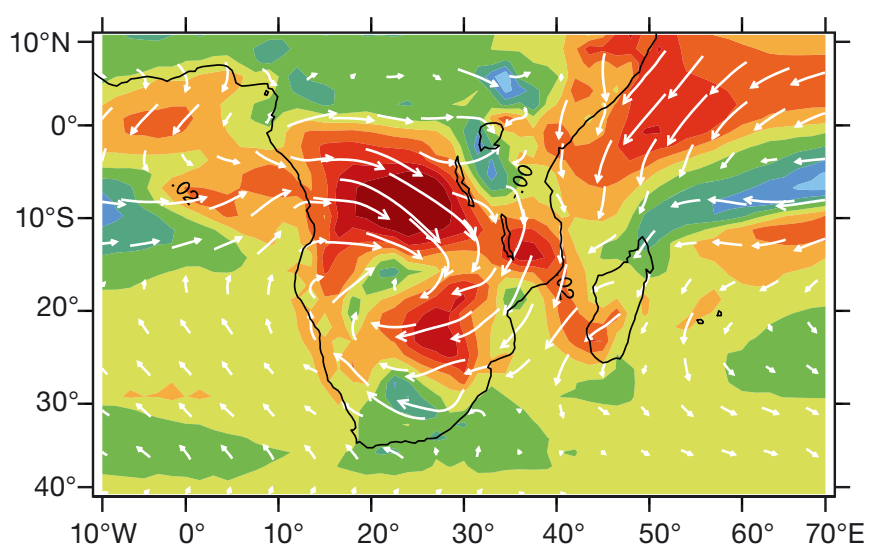

FGOALS-g2

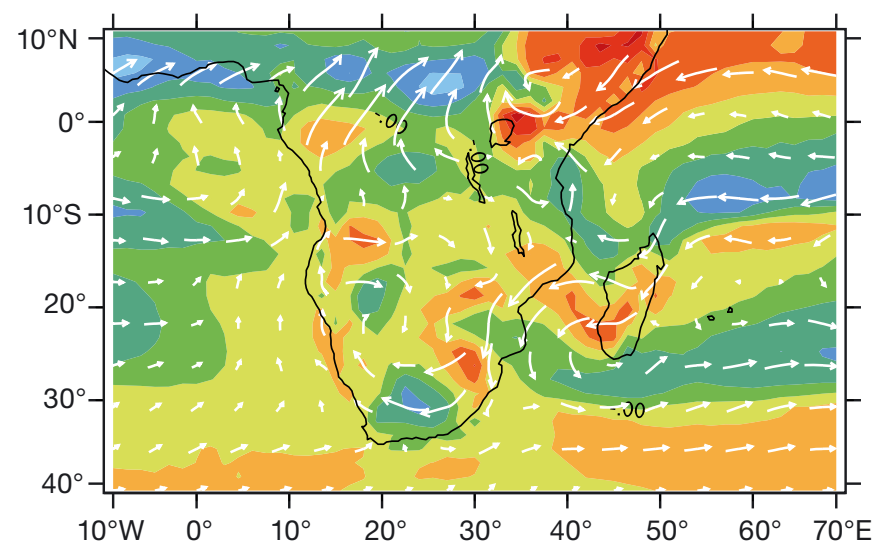

\section{MIROC-WSM-CHEM}

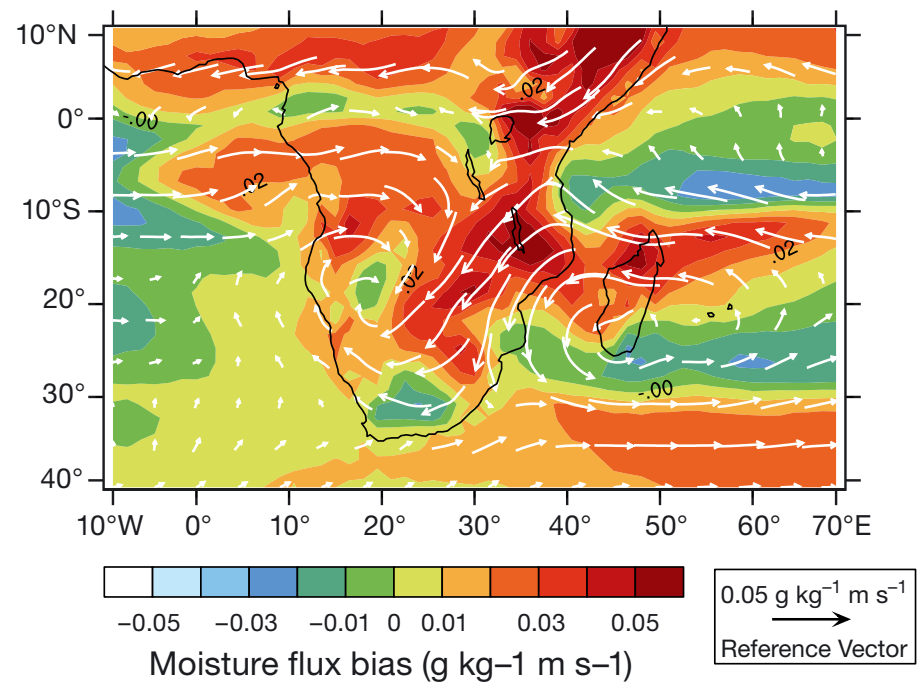

Fig. 6. As in Fig. 5a, but for 3 individual selected, contrasting models from the CMIP archive 


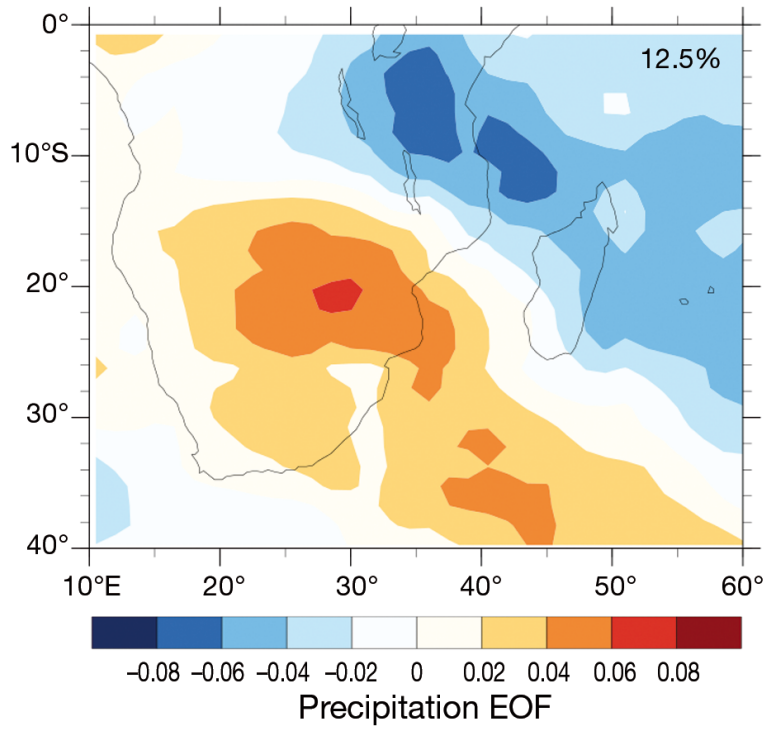

Fig. 7. Primary DJF precipitation empirical orthogonal function calculated for CMAP for the 30 yr period from 1979/802008/09. The percentage of the total variance explained is shown in the top right-hand corner of the plot

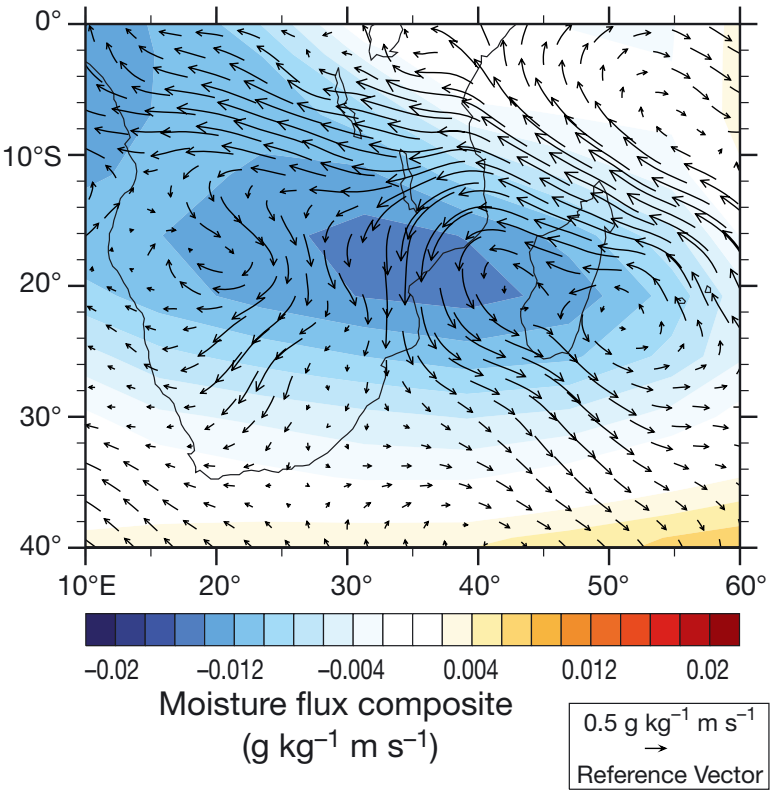

Fig. 8. Moisture transport patterns associated with shifts in the South Indian Ocean Convergence Zone (SIOCZ). $850 \mathrm{hPa}$ DJF moisture flux composite anomalies $\left(\mathrm{g} \mathrm{kg}^{-1} \mathrm{~m}\right.$ $\mathrm{s}^{-1}$ ) for the top 5 DJF seasons minus the bottom 5 DJF seasons of the CMAP precipitation empirical orthogonal function time series (see Section 4 for details)

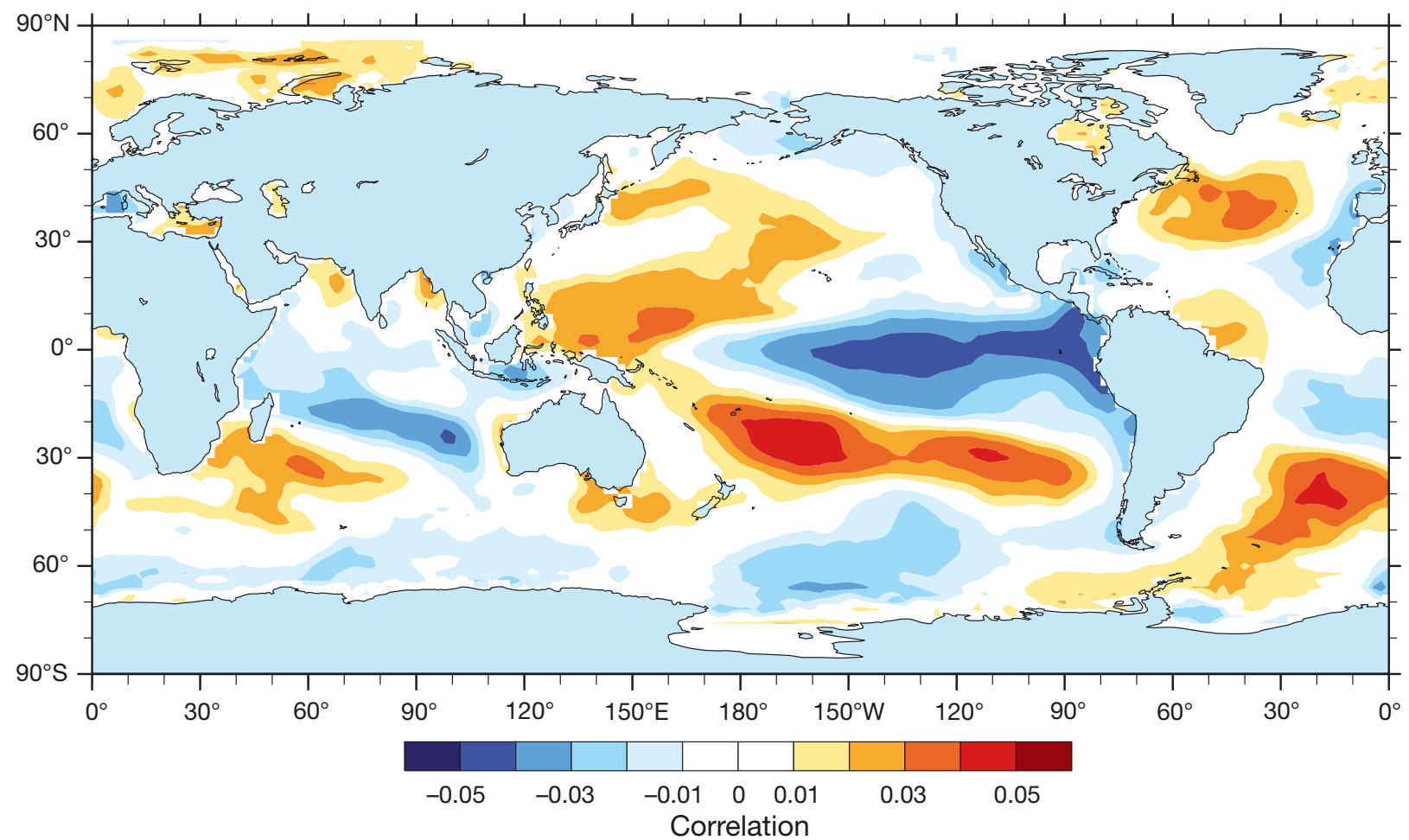

Fig. 9. Teleconnections associated with South Indian Ocean Convergence Zone (SIOCZ) variability. Correlation of CMAP EOF 1 time coefficients and observed global sea surface temperatures (SSTs) for DJF 1979/80-2008/09 
Table 3. Spatial correlations of CMAP empirical orthogonal function (EOF) 1 against model EOF1, 2 or 3 (whichever is highest) and temporal correlations of CMIP5 models EOF 1 against the Niño3.4 index and the subtropical Indian Ocean dipole (SIOD) index. Bold: significant correlations at $95 \%$ confidence interval. (/) Not applicable

\begin{tabular}{|c|c|c|c|}
\hline $\begin{array}{l}\text { Model/ } \\
\text { observation }\end{array}$ & $\begin{array}{c}\text { EOF } \\
\text { spatial } \\
\text { correlation }\end{array}$ & $\begin{array}{l}\text { Temporal } \\
\text { correlation } \\
\text { of EOF } 1 \\
\text { vs. Niño3.4 }\end{array}$ & $\begin{array}{c}\text { Temporal } \\
\text { correlation } \\
\text { of EOF } 1 \\
\text { vs. SIOD }\end{array}$ \\
\hline CMAP & I & -0.39 & -0.37 \\
\hline ACCESS1-0 & -0.69 & -0.25 & -0.06 \\
\hline ACCESS1-3 & 0.41 & -0.01 & -0.09 \\
\hline bcc-csm1-1 & -0.51 & 0.07 & -0.21 \\
\hline bcc-csm1-1-m & -0.61 & 0.24 & -0.11 \\
\hline BNU-ESM & -0.35 & -0.42 & 0.15 \\
\hline CanESM2 & -0.83 & -0.04 & 0.04 \\
\hline CCSM4 & 0.53 & -0.27 & 0.19 \\
\hline CESM1-BGC & 0.61 & 0.30 & -0.03 \\
\hline CESM1-CAM5 & -0.40 & 0.12 & 0.01 \\
\hline CESM1-FASTCHEM & -0.50 & 0.25 & 0.02 \\
\hline CESM1-WACCM & 0.62 & -0.15 & 0.01 \\
\hline CMCC-CESM & -0.33 & 0.21 & 0.03 \\
\hline CMCC-CM & -0.69 & -0.01 & 0.05 \\
\hline CMCC-CMS & -0.83 & 0.09 & 0.10 \\
\hline CNRM-CM5 & -0.41 & -0.30 & -0.10 \\
\hline CSIRO-Mk3-6-0 & 0.53 & -0.29 & -0.11 \\
\hline EC-EARTH & -0.72 & -0.03 & -0.02 \\
\hline FGOALS-g2 & -0.54 & 0.16 & 0.07 \\
\hline FGOALS-s2 & -0.68 & 0.01 & 0.02 \\
\hline FIO-ESM & -0.55 & -0.05 & 0.05 \\
\hline GFDL-CM3 & -0.71 & -0.11 & 0.04 \\
\hline GFDL-ESM2G & 0.54 & -0.06 & 0.05 \\
\hline GFDL-ESM2M & 0.68 & -0.43 & 0.16 \\
\hline GISS-E2-H & 0.54 & -0.10 & 0.21 \\
\hline GISS-E2-H-CC & -0.69 & 0.07 & 0.24 \\
\hline GISS-E2-R & -0.38 & 0.02 & 0.03 \\
\hline GISS-E2-R-CC & 0.43 & 0.10 & -0.06 \\
\hline HadGEM2-AO & 0.58 & 0.05 & -0.15 \\
\hline HadGEM2-CC & 0.68 & 0.09 & 0.02 \\
\hline HadGEM2-ES & -0.28 & 0.00 & 0.17 \\
\hline INMCM4 & -0.51 & 0.24 & -0.09 \\
\hline IPSL-CM5A-LR & -0.63 & -0.10 & 0.15 \\
\hline IPSL-CM5A-MR & 0.61 & 0.01 & -0.09 \\
\hline IPSL-CM5B-LR & -0.47 & -0.11 & -0.21 \\
\hline MIROC4h & -0.46 & 0.05 & 0.04 \\
\hline MIROC5 & 0.44 & -0.19 & 0.11 \\
\hline MIROC-ESM-CHEM & 0.81 & -0.10 & -0.34 \\
\hline MIROC-ESM & -0.79 & 0.02 & -0.02 \\
\hline MPI-ESM-LR & -0.4 & -0.21 & 0.11 \\
\hline MPI-ESM-MR & 0.58 & 0.11 & -0.10 \\
\hline MPI-ESM-P & 0.55 & -0.11 & 0.24 \\
\hline MRI_CGCM3 & 0.49 & -0.20 & 0.14 \\
\hline NorESM1-M & 0.25 & 0.10 & -0.20 \\
\hline NorESM1-ME & 0.39 & -0.07 & -0.25 \\
\hline
\end{tabular}

for this break could be the different dynamics within models over land and ocean.

These systematic biases implied the need to identify the cause (potentially excessive moisture flux convergence in models, Washington et al.
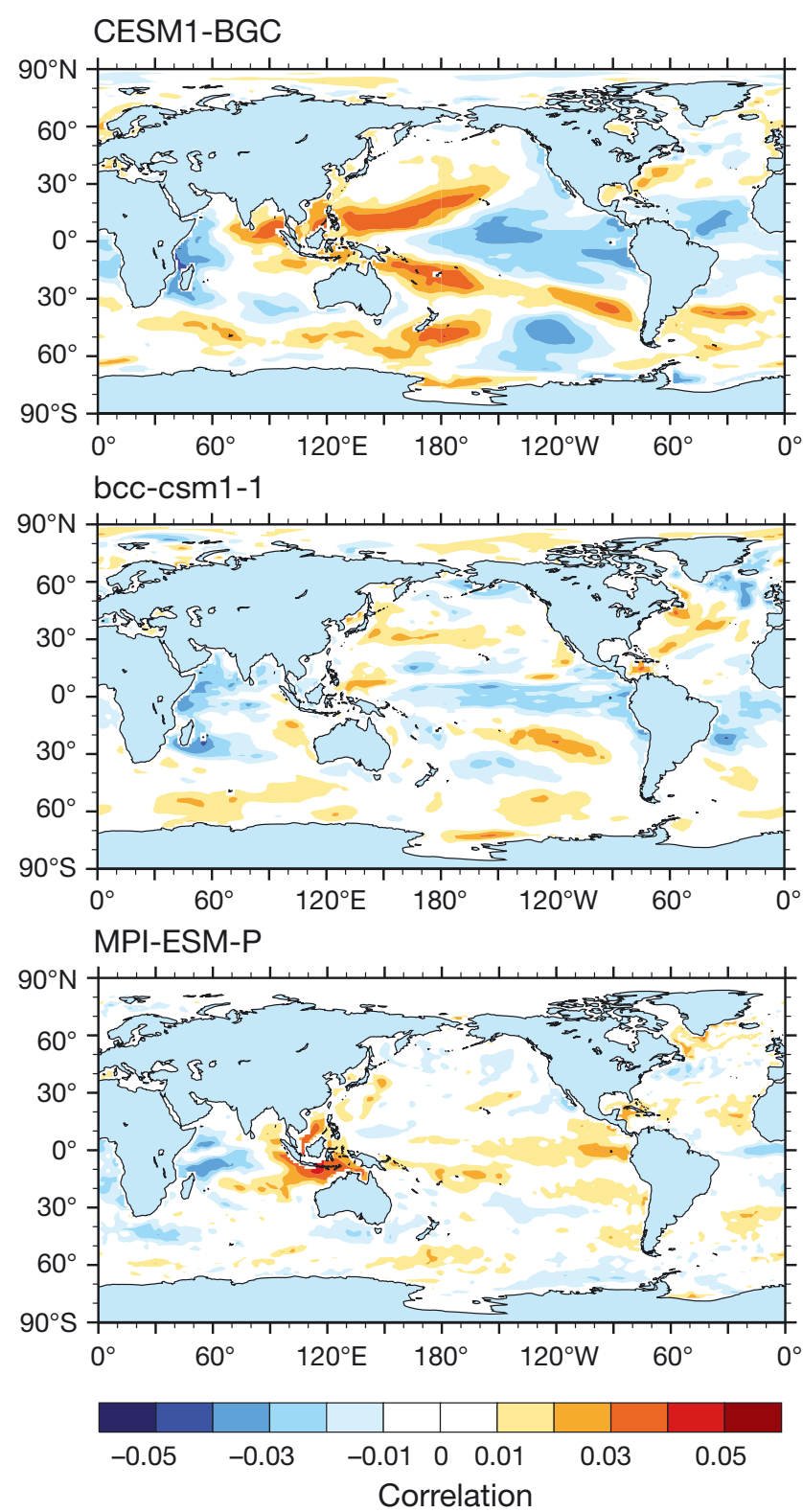

Fig. 10. As in Fig. 9, but for 3 selected and contrasting CMIP models (CESM1-BGC: good, bcc-csm1-1: average, and MPIESM_P: poor)

2013; and SST biases in models, e.g. Brown et al. 2011) so these can be corrected for in models. Therefore, biases in model moisture flux were investigated and were found to be anomalously high around the Angola Low. The bias is mainly due to large-scale circulation biases and not specific humidity biases (Fig. 5).

SSTs showed a small negative bias over the Indian Ocean region in the $\mathrm{MME}$, and are therefore not linked to the excessive precipitation through overly warm ocean temperatures resulting in more convec- 
tion and hence rainfall. Further studies are required to understand this Indian Ocean precipitation bias; SST gradients in models may also be a potential contributor.

The EOF analysis provided the pattern of variability of the SIOCZ with the typical mean position of the SIOCZ located between the dipole pattern found in the primary EOF. This primary EOF also correlated significantly to Niño3.4 and the SIOD in observations. The dipole pattern found in EOF 1 could be interpreted as the movement or shift of the SIOCZ in wet and dry years, i.e. La Niña and El Niño years, respectively, similar to the north-south displacement of the SPCZ during El Niño and La Niña years, which is well captured by most CMIP3 (Brown et al. 2011) and CMIP5 (Brown et al. 2013) models. Most CMIP5 and AMIP (not shown) models captured the primary EOF dipole pattern consistent with observations, which implies that the models do exhibit characteristics of variability to some extent, which is a step further in our understanding of model processes and dynamics. SIOCZ rainfall is complex in terms of variability, as it is not just influenced by one major source but potentially several, e.g. wave activity such as Rossby waves and the Matsuno-Gill response (Ratnam et al. 2014).

The large-scale circulation of the SIOCZ was linked through to variability via composite analysis of the primary observed EOF time series and moisture flux fields. Variability is dominated by moisture flux pathway 3 (anti-cyclonic circulation around the SIOHP), feeding into the eastern parts of southern Africa. This anomalous circulation of moisture flux highlights the change of importance in the 3 moisture flux pathways.

There is a significant influence of ENSO and the SIOD on the meridonal position of the SIOCZ found in observations; however, the CMIP5 and AMIP models were not able to significantly capture this relationship. Models make the SIOCZ shift north and southwards but not for the correct reasons, i.e. weak correlations with Indian Ocean and Pacific SSTs. Implications are that future climate change signals will be partly due to changes in SST gradients in the Pacific and Indian Ocean (e.g. changes to ENSO; Power et al. 2006, Alder 2011, Stevenson 2012). Therefore, models need to correctly simulate teleconnections at present, so future analyses can be valuable.

This paper is the first in which CMIP5 models are evaluated regarding their ability to capture the climatology and variability of the SIOCZ. These results have implications for regional climate projections using the set of CMIP5 models, such as which models are more accurate in capturing both mean state and variability (bcc-csm1-1 and bcc-csm1-1-m). Other implications include where biases are likely to be important within CMIP5 models, such as in regions with excessive moisture convergence in those areas. Further work is needed to explore what processes are responsible for the model precipitation biases, and what other potential drivers are driving variability within CMIP5 models besides the observed influence of ENSO and the SIOD.

Acknowledgements. This work was supported by the Peter Carpenter Scholarship for African Climate Change through the University of Sussex and the Natural Environment Research Council (NERC) Future Climate for Africa (FCFA) regional consortium project 'UMFULA', reference: NE/ M020258. We also acknowledge the World Climate Research Programme's Working Group on Coupled Modelling responsible for the CMIP5 model data, which were provided by the Program for Climate Model Diagnosis and Intercomparison (PCMDI). More information on these model data can be found at the PCMDI website (www-pcmdi. llnl.gov/).

\section{LITERATURE CITED}

Adler RF, Huffman GJ, Chang A, Ferraro R and others (2003) The version-2 global precipitation climatology project (GPCP) monthly precipitation analysis (1979present). J Hydrometeorol 4:1147-1167

Alder JR (2011) Simulating past, present, and future changes in ENSO: a model evaluation and data-model comparison. $\mathrm{PhD}$ dissertation, Oregon State University, Corvallis, OR

Battisti DS, Bhatt US, Alexander MA (1995) A modeling study of the interannual variability in the wintertime North Atlantic Ocean. J Clim 8:3067-3083

- Behera SK, Yamagata T (2001) Subtropical SST dipole events in the southern Indian Ocean. Geophys Res Lett 28:327-330

> Bollasina MA, Ming Y (2013) The general circulation model precipitation bias over the southwestern equatorial Indian Ocean and its implications for simulating the South Asian monsoon. Clim Dyn 40:823-838

Brown JR, Power SB, Delage FP, Coleman RA, Moise AF, Murphy BF (2011) Evaluation of the South Pacific Convergence Zone in IPCC AR4 climate model simulations of the twentieth century. J Clim 24:1565-1582

Brown JR, Moise AF, Colman RA (2013) The South Pacific Convergence Zone in CMIP5 simulations of historical and future climate. Clim Dyn 41:2179-2197

Callaway JM (2004) Adaptation benefits and costs: Are they important in the global policy picture and how can we estimate them? Glob Environ Change 14:273-282

Collins M, Knutti R, Arblaster J, Dufresne JL and others (2013) Long-term climate change: projections, commitments and irreversibility. In: Stocker TF, Qin D, Plattner GK, Tignor $M$ and others (eds) Climate change 2013: the physical science basis. Contribution of Working Group I to the Fifth Assessment Report of the Intergovernmental Panel on Climate Change. Cambridge University Press, 
Cambridge and New York, NY, p 1029-1136

Cook KH (1998) On the response of the Southern Hemisphere to ENSO. Proc 23rd Climate Diagnostics and Prediction Workshop, Miami, FL. American Meteorological Society, p 323-326

Cook KH (2000) The South Indian Convergence Zone and interannual rainfall variability over southern Africa. J Clim 13:3789-3804

Cook KH (2001) A Southern Hemisphere wave response to ENSO with implications for southern Africa precipitation. J Atmos Sci 58:2146-2162

> Dee DP, Uppala SM, Simmons AJ, Berrisford P and others (2011) The ERA-Interim reanalysis: configuration and performance of the data assimilation system. QJR Meteorol Soc 137:553-597

Engelbrecht FA, McGregor JL, Engelbrecht CJ (2009) Dynamics of the Conformal-Cubic Atmospheric Model projected climate-change signal over southern Africa. Int J Climatol 29:1013-1033

> Gates WL (1992) AMIP: the Atmospheric Model Intercomparison Project. Bull Am Meteorol Soc 73:1962-1970

> Gates WL, Boyle JS, Covey C, Dease CG and others (1999) An overview of the results of the Atmospheric Model Intercomparison Project (AMIP I). Bull Am Meteorol Soc 80:29-55

Gleckler PJ, Taylor KE, Doutriaux C (2008) Performance metrics for climate models. J Geophys Res 113:D06104, doi:10.1029/2007JD008972

Goddard L, Graham NE (1999) Importance of the Indian Ocean for simulating rainfall anomalies over eastern and southern Africa. J Geophys Res 104:19099-19116

Hoerling M, Hurrell J, Eischeid J, Phillips A (2006) Detection and attribution of twentieth-century northern and southern African rainfall change. J Clim 19:3989-4008

James R, Washington R, Jones R (2015) Process based assessment of an ensemble of climate projections for West Africa. J Geophys Res Atmos 120:1221-1238

Knutti R, Furrer R, Tebaldi C, Cermak J, Meehl GA (2010) Challenges in combining projections from multiple climate models. J Clim 23:2739-2758

Liebmann B, Kiladis GN, Marengo J, Ambrizzi T, Glick JD (1999) Submonthly convective variability over South America and the South Atlantic convergence zone. J Clim 12:1877-1891

Makarau A, Jury MR (1997) Predictability of Zimbabwe summer rainfall. Int J Climatol 17:1421-1432

Meehl GA, Stocker TF, Collins WD, Friedlingstein P and others (2007) Global climate projections. In: Solomon S, Qin D, Manning M, Chen Z and others (eds) Climate Change 2007: the physical science basis. Contribution of Working Group I to the Fourth Assessment Report of the Intergovernmental Panel on Climate. Cambridge University Press, Cambridge

Nicholson SE, Leposo D, Grist J (2001) The relationship between El Niño and drought over Botswana. J Clim 14: 323-335

Ninomiya K (2008) Similarities and differences among the South Indian Ocean convergence zone, North American convergence zone, and other subtropical convergence zones simulated using an AGCM. J Meteorol Soc Jpn 86: 141-165

Power S, Haylock M, Colman R, Wang X (2006) The predictability of interdecadal changes in ENSO activity and ENSO teleconnections. J Clim 19:4755-4771

Ratnam JV, Behera SK, Masumoto Y, Yamagata T (2014) Remote effects of El Niño and Modoki events on the austral summer precipitation of southern Africa. J Clim 27: 3802-3815

> Reason CJC (2001) Subtropical Indian Ocean SST dipole events and southern African rainfall. Geophys Res Lett 28:2225-2227

Renwick JA, Revell MJ (1999) Blocking over the South Pacific and Rossby wave propagation. Mon Weather Rev 127:2233-2247

Reynolds RW, Smith TM, Liu C, Chelton DB, Casey KS, Schlax MG (2007) Daily high-resolution-blended analyses for sea surface temperature. J Clim 20:5473-5496

Rowell DP (2013) Simulating SST teleconnections to Africa: What is the state of the art? J Clim 26:5397-5418

Schaller N, Mahlstein I, Cermak J, Knutti R (2011) Analyzing precipitation projections: a comparison of different approaches to climate model evaluation. J Geophys Res 116:D10118, doi:10.1029/2010JD014963

> Shongwe ME, van Oldenborgh GJ, van den Hurk B, van Aalst M (2011) Projected changes in mean and extreme precipitation in Africa under global warming. II. East Africa. J Clim 24:3718-3733

Stevenson SL (2012) Significant changes to ENSO strength and impacts in the twenty first century: results from CMIP5. Geophys Res Lett 39:L17703, doi:10.1029/2012 GL052759

> Sushama L, Laprise R, Caya D, Frigon A, Slivitzky M (2006) Canadian RCM projected climate-change signal and its sensitivity to model errors. Int J Climatol 26:2141-2159

Taylor KE (2001) Summarizing multiple aspects of model performance in a single diagram. J Geophys Res 106: 7183-7192

Taylor KE, Stouffer RJ, Meehl GA (2012) An overview of CMIP5 and the experiment design. Bull Am Meteorol Soc 93:485-498

Thibeault JM, Seth A (2014) A framework for evaluating model credibility for warm-season precipitation in northeastern North America: a case study of CMIP5 simulations and projections. J Clim 27:493-510

Tyson PD (1986) Climatic change and variability in Southern Africa. Oxford University Press, Capetown

- Washington R, James R, Pearce H, Pokam WM, MoufoumaOkia W (2013) Congo Basin rainfall climatology: Can we believe the climate models? Philos Trans R Soc Lond B Biol Sci 368:20120296

- Xie P, Arkin PA (1997) Global precipitation: a 17-year monthly analysis based on gauge observations, satellite estimates, and numerical model outputs. Bull Am Meteorol Soc 78:2539-2558

> Yin X, Gruber A, Arkin P (2004) Comparison of the GPCP and CMAP merged gauge-satellite monthly precipitation products for the period 1979-2001. J Hydrometeorol 5:1207-1222

Submitted: October 14, 2015; Accepted: February 18, 2016 Proofs received from author(s): April 4, 2016
Editorial responsibility: Filippo Giorgi,

Trieste, Italy 